\title{
Flood recovery and property acquisition in Cedar Rapids, Iowa
}

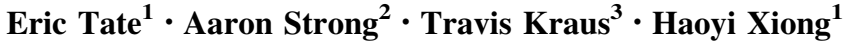

Received: 10 January 2015/Accepted: 24 October 2015/Published online: 31 October 2015

(C) The Author(s) 2015. This article is published with open access at Springerlink.com

\begin{abstract}
Voluntary property acquisitions are playing an increasingly prominent role in the aftermath of US flood disasters, as policy tools for community recovery and hazard mitigation. Following historic flooding in 2008, the City of Cedar Rapids, Iowa, instituted a federally supported program for the acquisition of over 1300 damaged properties. Using Cedar Rapids as a case study, this article investigates post-flood property acquisition from the perspectives of cost effectiveness and social equity. To assess economic viability, a benefit-cost analysis was performed at the parcel scale. Social equity was assessed using a social vulnerability index tailored to flood recovery. The results indicate that the property acquisitions are cost effective based on the avoidance of future flood losses, and prioritize socially vulnerable neighborhoods. The dual economic and social analysis sheds light on the capacity of federally supported buyouts to support holistic post-disaster planning and decision-making.
\end{abstract}

Keywords Disaster recovery $\cdot$ Social vulnerability $\cdot$ Benefit-cost analysis · Buyouts

Eric Tate

eric-tate@uiowa.edu

Aaron Strong

astrong@rand.org

Travis Kraus

tkraus@mountpleasantiowa.org

Haoyi Xiong

haoyi-xiong@uiowa.edu

1 Department of Geographical and Sustainability Sciences, University of Iowa, 316 Jessup Hall, Iowa City, IA 52242, USA

2 RAND Corporation, 1200 South Hayes Street, Arlington, VA 22202-5050, USA

3 Mount Pleasant Area Chamber Alliance, 124 S Main Street, Mount Pleasant, IA 52641, USA 


\section{Introduction}

In June 2008, following a winter of heavy snowfall and a spring with high-intensity rains, a broad swath of the Midwestern United States experienced significant flooding (Krajewski and Mantilla 2010). The City of Cedar Rapids, Iowa, was particularly hard hit by flooding along the Cedar River, which remained at or above flood stage for several weeks. The river ultimately crested at a stage of 31.1 feet, surpassing the previous record by more than 11 feet (USGS 2014). The flooding extended well beyond the mapped 500-year floodplain boundary, inundating over 10 square miles and 1300 city blocks, displacing more than 18,000 residents, and generating over $\$ 3$ billion in economic losses (City of Cedar Rapids 2010). Moreover, the flooded areas overlapped the majority of the affordable housing stock within the city, with many affected residents subsequently unable to afford housing in undamaged areas.

In the weeks following the flood, Cedar Rapids began the recovery process, bringing together residents, hazard and planning experts, and government agencies to devise a recovery and redevelopment plan. The 10-month public participation planning process resulted in the River Corridor Redevelopment Plan and a preferred flood management strategy. Guided by the principles of environmental justice and sustainability, the strategy combined levees, removable floodwalls, green space, and neighborhood revitalization. A key element of the recovery plan was the acquisition of 1356 flood-affected properties.

This article examines the degree to which property acquisitions in Cedar Rapids support hazard mitigation and revitalization of vulnerable neighborhoods. Two research questions form the basis for the analysis. First, were the acquisitions a cost-effective way to reduce future flood damage? To investigate, we conducted a benefit-cost analysis for the acquired properties. Second, did the property acquisitions target disadvantaged areas? To address this question, we developed a social vulnerability index tailored to flood recovery and used it to evaluate the distribution of property acquisition resources in terms of social equity.

\section{Federal programs for post-disaster property acquisition}

Nationwide, voluntary property acquisitions ("buyouts") are playing an increasingly important policy role after flood disasters (Zavar 2015). Through buyout programs, owners of severely damaged properties are offered pre-flood fair market values for their properties, and given an opportunity to move from difficult circumstances (Fraser et al. 2003). When acquired parcels are permanently converted to green space or wetlands, they enhance hazard mitigation by eliminating future property losses, reduce threats to residents and first responders, and provide environmental benefits through expanded ecological habitat, flood storage and conveyance, and recreational opportunities. However, past voluntary buyout programs have also generated resident feelings of coercion, degradation of trust, and loss of attachment to place (de Vries and Fraser 2012; Fraser et al. 2003).

The US Federal Emergency Management Agency (FEMA) has had voluntary buyout authority since the 1980s, but its use gained favor as a policy recommendation following the Mississippi River flooding of 1993 (Interagency Floodplain Management Review Committee 1994). With estimated losses of an estimated $\$ 34$ billion, the 1993 flood stands among the most devastating and costly disasters in US history (NOAA 2015), and led to policy shifts at the federal level toward non-structural mitigation (Fraser et al. 2003). The 
Robert T. Stafford Disaster Relief and Emergency Assistance Act of 1988 governs allocation of federal post-disaster assistance following a Presidential Disaster Declaration. A 1993 amendment to the Stafford Act increased the allowable portion of relief funds that could be applied to voluntary buyouts and other mitigation projects to $15 \%$, and increased the federal cost share from 50 to $75 \%$ (Conrad et al. 1998). Voluntary acquisition of damaged or destroyed properties occurs under the Stafford Act through the Hazard Mitigation Grant Program (HMGP).

The primary objectives of HMGP are to prevent future hazard risk to people and property, and enable mitigation activities to be integrated into disaster recovery. Properties acquired with HMGP funds are deed restricted against structural improvements, reverting in perpetuity to open space, recreational use, or natural floodplains (Conrad et al. 1998). Properties outside the 100-year flood boundary can be acquired with HMGP funds, but only if they meet FEMA's benefit-cost analysis (BCA) requirements. A FEMA BCA evaluates the future benefits in terms of projected avoided losses, acquisition costs, and maintenance costs over the same time period. If the ratio of benefits to costs exceeds 1.0, the acquisition is considered to be cost effective and becomes eligible for HMGP funding. For properties declared by the community as 'substantially damaged' by flooding and located within a mapped 100-year floodplain, property acquisition is automatically deemed to be cost effective and the benefit-cost requirements are waived (FEMA 2013). This economic justification for HMGP project selection increasingly aligns with demands of policy makers and decision-makers (Shreve and Kelman 2014), adopting a utilitarian perspective to disaster recovery in which resource distribution should focus on maximizing public utility (Johnson et al. 2007; Schulze and Kneese 1981).

The Community Development Block Grant Program (CDBG) is the second major source of federal assistance for post-disaster property acquisitions. CDBG funding for disaster recovery originates via special Congressional appropriations that route funds through the Department of Housing and Urban Development to state governments. The primary mission of CDBG is neighborhood revitalization and economic development, but appropriations related to disasters have expanded dramatically over the past decade. Between the years 2000 and 2013, disaster recovery grants constituted nearly half of all program disbursements (Spader and Turnham 2014).

CDBG is the most flexible funding source for disaster recovery because states have wide discretion in the design, allocation, and management of program funds. CDBG assistance can be applied toward short-term relief, long-term recovery, and hazard mitigation, to finance efforts including reconstruction, economic development, and voluntary property acquisitions. Any buyouts undertaken with CDBG funds must satisfy at least one of the program's three national objectives: (1) benefit people of low and moderate income (LMI); (2) aid in eliminating/preventing slums or blight; or (3) meet urgent community development needs that pose a serious and immediate public threat (HUD 2014b). Although the LMI requirement is the primary national objective, it is the third national objective of meeting urgent need that enables CDBG funds to be used for disaster recovery (Boyd 2011). Overall, the CDBG goals broadly align with a Rawlsian perspective to disaster recovery, in which the distribution of resources should focus on the most vulnerable (Johnson et al. 2007).

Although flexibility in the design and management of CDBG funds enables communities to use the program to serve a variety of purposes, it has also led to criticism. The lack of deed restrictions for CDBG buyouts outside the 100-year floodplain means that CDBG might promote redevelopment in previously flooded areas. Recent analysis of flood insurance claims data shows that between 30 and $47 \%$ of loss claims occur for properties 
located outside the $1 \%$ annual chance flood boundary (Highfield et al. 2013). A second critique concerns the LMI requirements, with "low income" defined as at least $50 \%$ below the area median income, and "moderate income" as at least $80 \%$ below the area median. CDBG income provisions require that at least $70 \%$ of the total allocation be directed to LMI persons (HUD 2014a), but the requirement has been waived by Congress in several instances (Gotham 2014). For the 2008 Midwest floods, the minimum proportion of LMIdirected funding was cut from 70 to $50 \%$, thus reducing the proportion of the $\$ 300$ million allocation targeted for the most vulnerable neighborhoods (Boyd 2011). In Cedar Rapids, this proportion was further reduced when the city was granted a waiver to raise the low and moderate thresholds from 50 and $80 \%$ of the area median income, to 80 and $100 \%$.

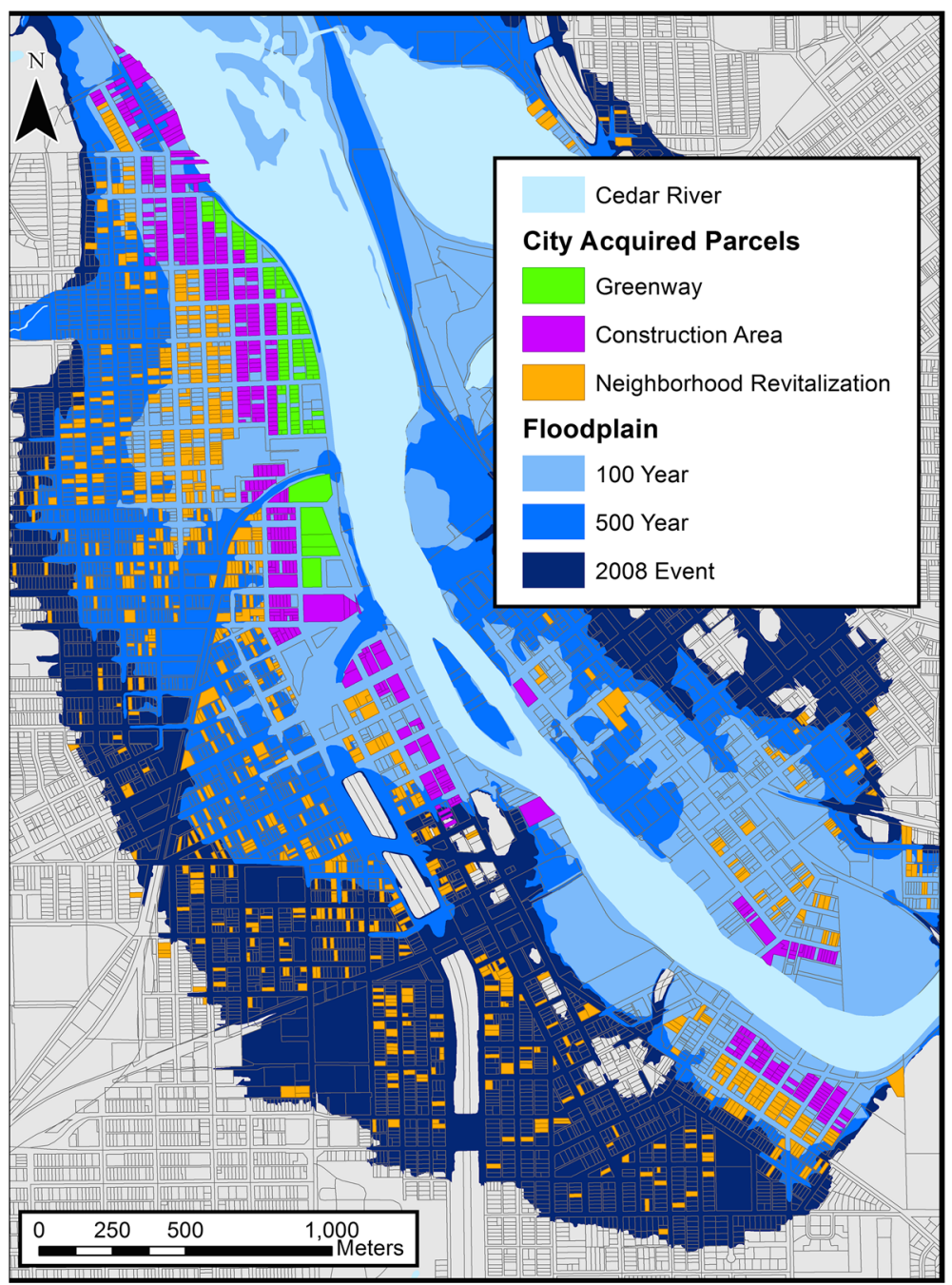

Fig. 1 Cedar Rapids flood zones, acquired parcels, and recovery/mitigation management areas 
Collectively, the property acquisition provisions of HMGP and CDBG provide an infusion of post-disaster resources that can further community goals in recovery and mitigation. Although the mission of HMGP is mitigation and that of CDBG is recovery, the lines between the two can be more fuzzy than distinct in the context of buyouts. Development decisions made in the name of recovery can strongly influence vulnerabilities to future hazard events (e.g., redevelopment in the floodplain), and those aimed at mitigation can affect the pace and equity of recovery (e.g., levee construction). Keeping in mind the central missions of HMGP and CDBG, this paper examines the buyouts under these programs.

\section{Property acquisition and flood recovery in Cedar Rapids}

The Voluntary Acquisition Program is a major component of the flood mitigation and longterm recovery process in Cedar Rapids, and combined funds from HMGP, CDBG, and the city. Eligibility for the program required that flood-damaged properties were located within the 100-year floodplain, in an LMI area, or determined to be "beyond reasonable repair." Property owners were offered $107 \%$ of the pre-flood assessed value, adjusted downward in cases with "duplication of benefits," such as funds already received through flood insurance payouts or FEMA Individual Assistance grants. By the time the program closed on June 30, 2014, Cedar Rapids had acquired 1356 flood-damaged properties for a total of $\$ 93.9$ million (Smith 2014). The buyouts served as part of a larger recovery and mitigation strategy that partitioned the 2008 floodplain into three management areas:

1. Construction Area for the erection of a structural flood management system.

2. Greenway Area located in the unprotected space between the Cedar River and the Construction Area.

3. Neighborhood Revitalization Area on the protected side of Construction Area.

Figure 1 displays the management areas and acquired properties, in relation to the 100-, 500-year, and 2008 floodplain boundaries. The acquisition pattern indicates differences in land use in Cedar Rapids, with primarily older residential neighborhoods on the west side of the river, and the central business district on the east side. The map also helps illustrate the nominal distinction between zones targeted for hazard mitigation (Greenway and Construction Areas) and disaster recovery (Neighborhood Revitalization Area).

The Greenway Area properties, many of which were purchased with HMGP funds, represent loss avoidance for future floods, as these parcels are deed restricted against development or infill. The Greenway properties occurred within the 100-year mapped floodplain and were declared 'substantially damaged' by the city, so a FEMA BCA was not required. The demolition and conversion to green space not only helps prevent loss of life and property, but also creates public recreational opportunities near the river. The planned 110-acre Greenway Project includes construction of a multi-use trail to connect three new riverside parks. Among the proposed amenities are picnic areas, soccer fields, skate and dog parks, a botanical garden, disc golf course, fishing pier, canoe/kayak launch, and openair pavilions (City of Cedar Rapids 2014). Reevaluating the value of rivers has been gaining momentum in many communities, which are increasingly developing plans to increase public enjoyment and recreational use of the waterways, whereas previously there had often been development right up to the riverbanks. Ironically, the City of Cedar Rapids had declared 2008 the "Year of the River" in an effort to build enthusiasm to reconnect the 
downtown area and the Cedar River. After the flood, the slogan took on an entirely different meaning. The creation of the Greenway Area creates an opportunity for the city to achieve that original goal.

The Construction Area will be part of a flood management system of levees and floodwalls and will also serve as public recreational space. Properties acquired in the Construction Area are within the 100-year floodplain, but were largely purchased with CDBG funds because the planned levee conflicts with HMGP deed restrictions against development and infill. The focus of the Neighborhood Revitalization Area is to develop affordable replacement workforce housing in neighborhoods incorporating walkability and a sense of place, while also providing opportunities for recreation and transportation. Most of the revitalization properties are located either within or outside of the 500-year flood zone. These properties were eligible for buyout through CDBG if the structure was 'substantially damaged' (damage state of at least $50 \%$ ) or posed a health and safety threat. Given the low probability of future flooding in the Neighborhood Revitalization Area, especially after the flood management system is installed, the acquisition of these properties contributes more to community development than flood mitigation. Much of the Neighborhood Revitalization Area is slated for housing redevelopment, with priority given to buyers with incomes below the area median value.

Table 1 describes the 1356 properties acquired by the city. The buyouts financed with CDBG funds account for $93 \%$ of the total and had a lower average cost. The deed restrictions for the 100-year flood zone are apparent in the distribution of buyouts for each program across recovery and flood zones. All of the HMGP buyouts occurred in the Greenway Area and 100-year flood zone, while CDBG was the only federal funding source for acquisitions in the Construction and Neighborhood Revitalization Areas in the 500-year and 2008 floodplains.

Cedar Rapids has used property acquisition to help achieve the goals of their flood recovery plan. But how likely are the buyouts to result in vulnerability reduction? First, were the buyouts economically cost effective in terms of mitigating future flood losses? Second, were the buyouts equitable with respect to vulnerable neighborhoods? To address these questions, our research methodology is based on two objectives:

1. Assess cost effectiveness by performing a benefit-cost analysis that compares property acquisition costs and future losses avoided to private property.

2. Assess distributive social equity by quantifying social vulnerability in the context of flood recovery and comparing it with a relative measure of buyout expenditures.

Table 1 Buyout statistics by program, management area, and flood zone

\begin{tabular}{|c|c|c|c|c|c|c|c|c|}
\hline \multirow[t]{2}{*}{ Program } & \multirow[t]{2}{*}{ Buyouts } & \multirow[t]{2}{*}{ Avg. cost } & \multicolumn{3}{|c|}{ Management area } & \multicolumn{3}{|c|}{ Flood zone } \\
\hline & & & Greenway & Construction & Revitalization & 100-year & 500-year & 2008 \\
\hline \multirow[t]{2}{*}{ HMGP } & 97 & $\$ 79,286$ & 97 & 0 & 0 & 97 & 0 & 0 \\
\hline & & & $100 \%$ & $0 \%$ & $0 \%$ & $100 \%$ & $0 \%$ & $0 \%$ \\
\hline \multirow[t]{2}{*}{ CDBG } & 1259 & $\$ 60,101$ & 47 & 424 & 788 & 594 & 494 & 168 \\
\hline & & & $4 \%$ & $34 \%$ & $63 \%$ & $47 \%$ & $39 \%$ & $14 \%$ \\
\hline
\end{tabular}




\section{Benefit-cost analysis for buyouts}

To perform a benefit-cost analysis for the buyout program, the benefits are first determined in terms of avoided losses. Because stream flow outcomes are stochastic, these benefit estimates are the expected reduction in damage (average annualized losses) that would occur given the distribution of stream flows. The benefits are then compared with the expenditures for the buyout program. Our analysis estimates the benefits for each parcel rather than simply aggregate benefits. Geospatial data describing the buyout locations were obtained from the City of Cedar Rapids GIS, while pre-flood property attributes were obtained from the Cedar Rapids Assessors Office.

The average annualized loss (AAL) for each parcel was determined via a three-step process. First, the distribution of annual peak flood stage was estimated assuming a generalized extreme value distribution to provide the associated probabilities of flood events and determine the return periods corresponding to specific flood stages. Second, for each acquired parcel, flood depth grids from the Iowa Flood Center were applied in HAZUS$\mathrm{MH}$ to model the damage state by flood stage. Finally, the AAL was calculated by combining the flood stage probabilities and modeled damage through a weighted average.

\subsection{Determining flood return periods}

Historical data for the USGS stream gage for the Cedar River at Cedar Rapids (USGS 2014) were used to determine the relationship between river discharge and flood return period. Figure 2 displays the annual peak discharge recorded since 1903, including a single data point in 1851. It illustrates that the 2008 peak discharge of 140,000 cubic feet per second (cfs) is an extreme historical outlier, nearly double the peak values recorded during major floods in 1929, 1961, 1965, and 1993. Prior to 2008, the highest flood stage recorded in Cedar Rapids was 20.0 feet in 1929, which led to levee construction (Peoples Weather Map 2015). The 2008 peak flow also dwarfs the FEMA 100- and 500-year discharge values of 87,000 and 112,000 cfs (FEMA 2010), as well as values updated by the US Army Corps of Engineers $(94,100$ and 122,000 cfs) in 2008 (USACE 2010).

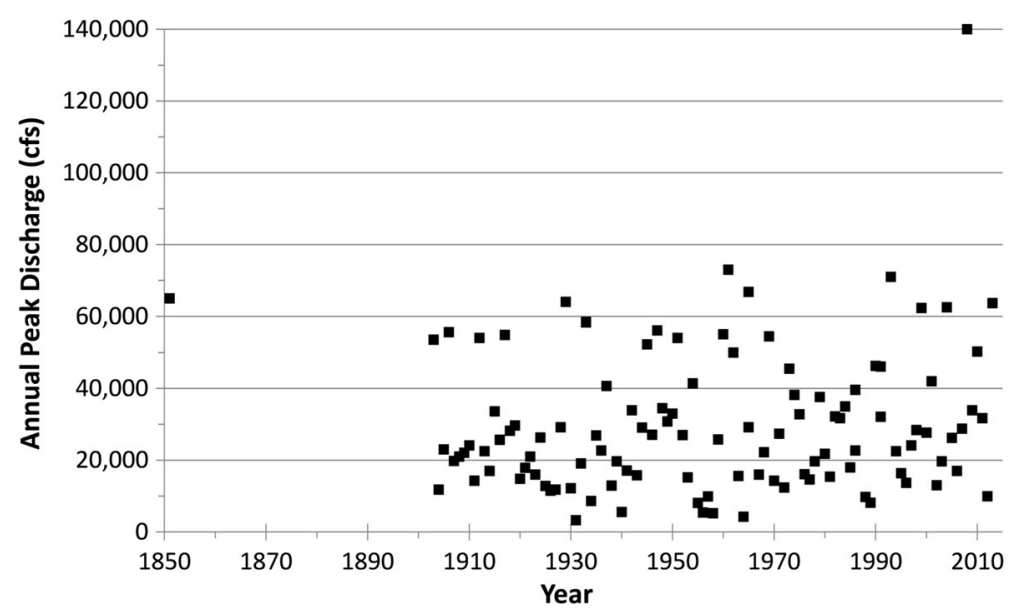

Fig. 2 Peak discharge (1851-2013) for the Cedar River at Cedar Rapids 
To estimate the distribution of extreme discharge values, the generalized extreme value (GEV) distribution is commonly used in the hydrologic literature (Villarini et al. 2011). Thus, we estimated a three-parameter GEV distribution over two samples: those including and excluding the 2008 observation. Maximum likelihood techniques were applied to estimate the parameters of the GEV, with the log likelihood function given by:

$$
\sum_{i}-\ln (\alpha)-\left(\frac{1}{k}+1\right) * \ln \left(1+k \frac{\left(x_{i}-\varphi\right)}{\alpha}\right)-\exp \left(\left(\frac{1}{k}\right) \ln \left(1+k \frac{\left(x_{i}-\varphi\right)}{\alpha}\right)\right)
$$

where $\alpha$ is the scale parameter, $k$ is the shape parameter, $\varphi$ is the location parameter, and $x_{i}$ is the maximum river stage for year $i$. The two GEV parameter estimations (2008 inclusive and exclusive) were used to determine the discharge-return period relationship from the inverse of the cumulative distribution function.

\subsection{Modeling flood losses}

The HAZUS-MH flood model was used to estimate physical damage and economic loss for each acquired parcel. HAZUS-MH is a GIS-based loss estimation model that combines flood depth grids, building characteristics, and depth-damage relationships to estimate monetary losses under varying user-designed scenarios (Scawthorn et al. 2006a, b). The resulting flood loss estimates are useful first approximations, but can also be associated with a significant degree of uncertainty (Ding et al. 2008; Tate et al. 2014). To develop more reliable estimates, we replaced HAZUS-MH default data with inputs of higher resolution and quality describing the flood hazard, building characteristics, and depth-damage functions.

Flood depth grids developed by the Iowa Flood Center were used to represent the flood hazard. The 5-m resolution grids were originally derived from a coupled 1D/2D hydrodynamic model based on a combination of inputs including gage observations, highresolution LiDAR topography, bathymetric survey, and surveys of structural elements. Among the key building characteristics for HAZUS-MH modeling are the building location, valuation, occupancy type (e.g., residential, commercial), foundation type, and firstfloor height. To customize the building model to Cedar Rapids, parcel locations and building attributes were obtained from the City of Cedar Rapids GIS and tax assessor offices. First-floor heights were estimated using HAZUS foundation type-to-height tables in the HAZUS technical manual (FEMA 2003). For assessor records lacking foundation type (e.g., crawlspace, basement), we assigned a slab-on-grade foundation. Collectively, the GIS and assessor data were used to bypass the coarse default building data in HAZUS that are aggregated at the geographic scale of US census blocks. Instead, we imported the building descriptions into HAZUS as user-defined facilities with specific point locations.

Because building footprint data were not available, the location of each building was assumed to occur at the parcel centroid. This assumption has the potential to introduce a high level of uncertainty for parcels that are geographically large and/or contain large elevation gradients. But given the mild slope and generally small parcel size within the Cedar Rapids floodplain, the centroid assumption is likely non-influential. In the damage assessment, we replaced the default HAZUS-MH depth-damage functions with a set developed by the US Army Corps of Engineers tailored to structures with basements (USACE 2003). Using these modeling inputs, HAZUS-MH computed the damage state and economic loss (structure + contents) for each parcel. 


\subsection{Estimating average annualized loss}

The GEV and loss estimates were combined by discretizing the integral of the product of damage and the probability of an observed flood stage. Central modeling questions in this process are how many and which return periods should be applied for estimating flood risk? Messner et al. (2007) suggest that a model with six flood return periods is preferred. Ward et al. (2011) tested this proposition and determined that moving from a roughly continuous integration to a discretization of between three and six points overestimates the damage between 33 and $100 \%$ depending on the choice of where to evaluate the distribution. Drawing on these findings, we estimated losses for 10 flood scenarios based on evaluation points that roughly correspond to the 2-, 5-, 10-, 25-, 50-, 100-, 250-, 500-, 1000-, and 2500-year return periods.

There are two important considerations when choosing evaluation points (Ward et al. 2011). First, the most frequent return period should be chosen such that it is the starting point for when damage occurs. Second, oversampling should occur where damage drastically increases. Since the AAL estimation is most sensitive to the high frequency events and, a priori, these properties for the damage function were unknown, over sampling of the high frequency events was chosen. To calculate the AAL for an acquired property, the sum of the product of damage and probabilities is constructed:

$$
\begin{aligned}
\mathrm{AAL}_{j}= & \sum_{i} \text { damage }_{i j} \times \operatorname{prob}(i) \\
& i=2,5,10,25,50,100,250,500,1000, \text { and } 2500
\end{aligned}
$$

where $i$ is the return period and $j$ is the property. Based on the 'substantially damaged' eligibility threshold (structure damage of at least $50 \%$ ) in the buyout programs, if damage exceeded $50 \%$, we recoded the damage as $100 \%$ of assessed value. To calculate the economic benefit for each acquired parcel, the discounted present value of benefits is required:

$$
\text { Benefits }_{i}=\sum_{t=0}^{T} \frac{\mathrm{AAL}_{i}}{(1+r)^{t}}
$$

where $\mathrm{r}$ is the discount rate and $T$ is the life of the property in years. This allows for the comparison of expected future benefits of avoided losses with the current costs to acquire the parcels. Following recommendations from the US Office of Management and Budget, we assume a 30-year property life and a discount rate of $3 \%$ (OMB 2013). The life of the property has only limited influence on the calculation, but the choice of discount rate plays a significant role in the determination of present value of benefits (Shreve and Kelman 2014). To provide an upper bound on avoided future losses, the discount rate of $3 \%$ was used because it is also a lower bound on discount rates used in practice. If the discount rate is increased, this will simply decrease the discounted present value of future losses, leading to a smaller benefits estimate.

Finally, the benefit-cost ratio for each parcel is computed by dividing the discounted future benefits by the acquisition cost. If a buyout is to be considered cost effective in reducing future losses, the benefit-cost ratio should exceed 1.0. This is particularly relevant for acquisitions financed by HMGP, whose principal goal is hazard mitigation. 


\section{Cost effectiveness of the buyouts}

Table 2 shows the values of the cumulative distribution function (CDF) by flood stage, inclusive and exclusive of the 2008 observations. The flood stages used in the AAL calculation (Eq. 2) roughly correspond to the 2-, 5-, 10-, 25-, 50-, 100-, 500-, 1000-, 2500 -year return periods when the 2008 data point is excluded. These are not exact return periods, so the estimated values of the CDF are instead employed, with differences between CDF estimates used as probabilities in the AAL calculation. For example, if the 2008 observation is included, the probability of a 24-foot flood stage is 0.006 (0.014-0.008). This is the difference in probability of a flood stage exceeding 24 feet minus the probability of a flood exceeding 26.5 feet.

Figure 3 displays the benefit-cost ratios at the parcel level for private structural and content losses, and Table 3 shows the crosstabs by program and benefit-cost ratios. Of particular interest is that a majority of the properties across the Greenway and Construction Areas would pass a benefit-cost test for avoided damage. For the Greenway Project, $88 \%$ of the parcels pass a benefit-cost test; for the Construction Area, $88 \%$ of the parcels would pass; and for the Neighborhood Revitalization, $46 \%$ would pass. FEMA's benefit-cost tool automatically includes environmental benefits when the benefit-cost ratio is $>0.75$. If we expand the criterion for passing the benefit-cost test to 0.5 instead of 1 , due to potential public benefits, the proportions of properties satisfying a benefit-cost test jumps to 95, 99, and $79 \%$, respectively. Essentially, if our estimates of the benefits were off by a factor of two, a vast majority of the properties would pass a benefit-cost test.

Although there is a greater percentage of parcels in the Neighborhood Revitalization Area that have a lower benefit-cost ratio, this is to be expected. The aim of the Neighborhood Revitalization is not to mitigate future damage, but to recover from the flood. Most of the parcels acquired in the Construction Area pass a benefit-cost test but are ineligible for HMGP funding because they will be developed as flood barriers to future potential large-scale events.

Table 2 Parameters for average annualized loss computation

\begin{tabular}{|c|c|c|c|c|c|c|}
\hline \multirow{2}{*}{$\begin{array}{l}\text { Flood } \\
\text { stage }\end{array}$} & \multicolumn{3}{|c|}{ Year 2008 excluded } & \multicolumn{3}{|c|}{ Year 2008 included } \\
\hline & $\begin{array}{l}\text { Return } \\
\text { period }\end{array}$ & $\mathrm{CDF}$ & $\begin{array}{l}\text { Probability for AAL } \\
\text { calculation }\end{array}$ & $\begin{array}{l}\text { Return } \\
\text { period }\end{array}$ & $\mathrm{CDF}$ & $\begin{array}{l}\text { Probability for } \\
\text { AAL } \\
\text { calculation }\end{array}$ \\
\hline 9.5 & 2 & 0.56 & 0.37 & 2 & 0.55 & 0.36 \\
\hline 14.0 & 5 & 0.18 & 0.096 & 5 & 0.19 & 0.09 \\
\hline 16.5 & 11 & 0.092 & 0.054 & 10 & 0.10 & 0.055 \\
\hline 19.5 & 27 & 0.037 & 0.017 & 22 & 0.046 & 0.018 \\
\hline 21.5 & 50 & 0.020 & 0.010 & 36 & 0.027 & 0.013 \\
\hline 24.0 & 109 & 0.009 & 0.005 & 68 & 0.014 & 0.007 \\
\hline 26.5 & 242 & 0.004 & 0.002 & 126 & 0.008 & 0.004 \\
\hline 29.0 & 538 & 0.002 & 0.0008 & 230 & 0.004 & 0.001 \\
\hline 31.0 & 1026 & 0.001 & 0.0006 & 368 & 0.003 & 0.001 \\
\hline 34.0 & 2718 & 0.0003 & 0.0004 & 730 & 0.001 & 0.001 \\
\hline
\end{tabular}




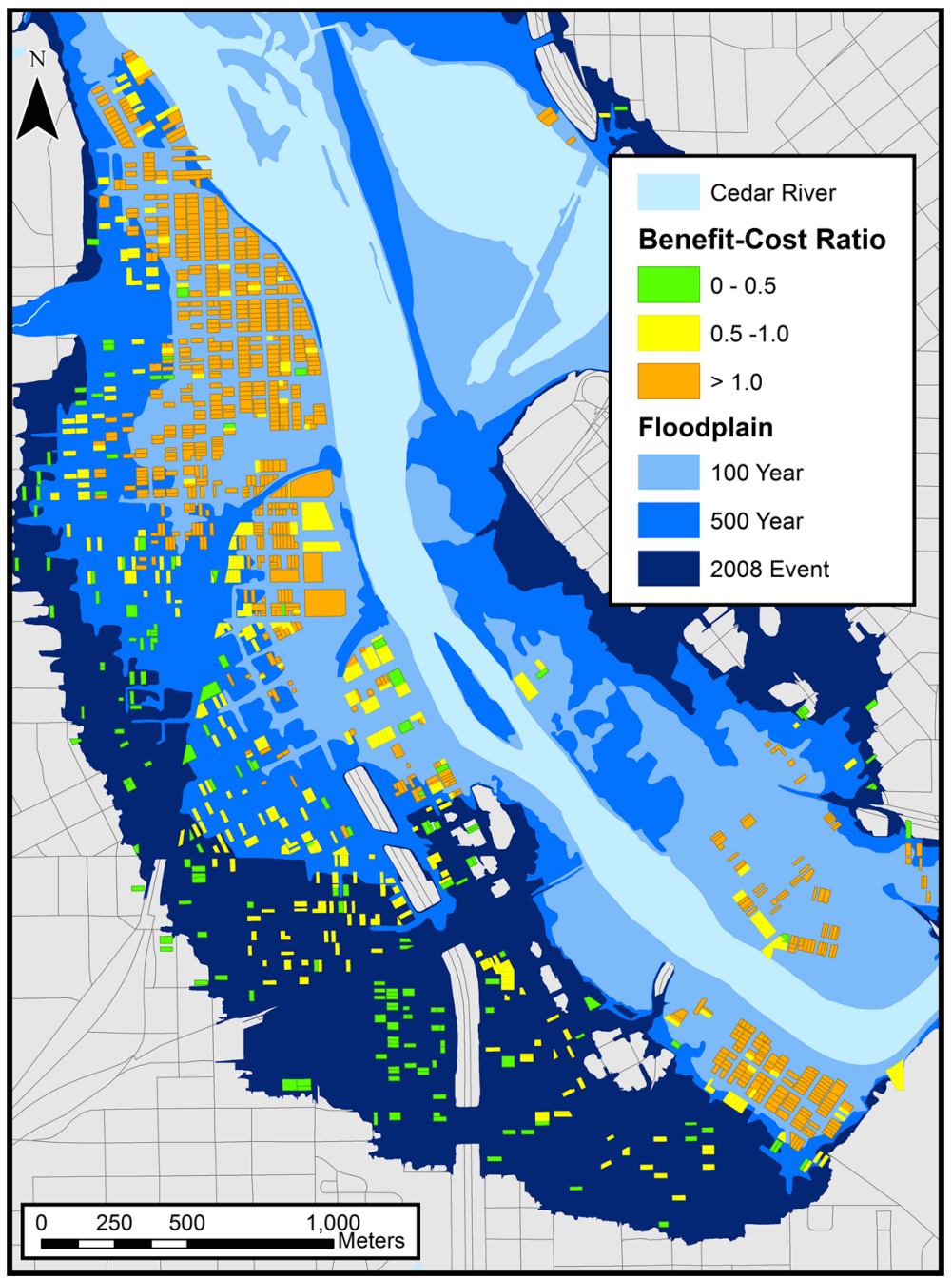

Fig. 3 Spatial distribution of benefit-cost ratios

Table 3 Benefit-cost ratios by management area

\begin{tabular}{llccr}
\hline Management area & BCR $>1$ & $0.5<$ BCR $<1$ & BCR $<0.5$ & Total \\
\hline Greenway & 126 & 10 & 8 & 144 \\
Construction & 373 & 45 & 6 & 424 \\
Neighborhood Revitalization & 366 & 258 & 164 & 788 \\
Total & 865 & 313 & 178 & \\
\hline
\end{tabular}

To test the influence of the discount rate on the BCA, we performed the same analysis with a $5 \%$ discount rate. Only two properties fail the benefit-cost test that would have passed with the $3 \%$ discount rate. With further increases in the discount rate, more 
properties would fail. The approach of recoding properties that receive more than $50 \%$ damage as a total loss is slightly more influential, as fifteen properties would fail the benefit-cost test that would not otherwise.

\section{A social vulnerability index for flood recovery}

Social vulnerability to hazards is based on the notion that the characteristics and situations of some population groups result in a disproportionately lower "capacity to anticipate, cope with, resist, and recover from the impact of a natural hazard" (Wisner et al. 2004, p. 11). Measuring social vulnerability using indicators has become an increasingly common practice, based on the understanding that vulnerability is a multidimensional construct not synonymous with poverty (Wisner et al. 2004). Most social vulnerability indices now include indicators of socioeconomic status, age, race and ethnicity, gender, functional needs, home ownership, health, and language proficiency (Cutter et al. 2003; Phillips et al. 2010) that serve as proxies for the underlying social, economic, institutional, and political drivers of human vulnerability to hazards. In the aftermath of the 2008 flood, the City of Cedar Rapids constructed social vulnerability indicators to argue (unsuccessfully) that new federally funded levees should protect not only the central business district on the east side of the river (medium benefit-cost ratio), but also socially vulnerable neighborhoods on the west side (low benefit-cost ratio; City of Cedar Rapids 2010).

A growing critique of quantitative indicators of social vulnerability is that they are limited in their capacity to reflect the context in which the disaster takes place (Fekete 2012; Kuhlicke et al. 2011). Important aspects of context include the hazard type, geographic setting, governance, concurrent economic conditions, historical processes, and cultural norms. Although contextual information is often absent from indicator studies, qualitative disaster case studies do provide that type of perspective. As a general principle, modeling decisions during construction of a social vulnerability indicator should reflect the conditions of the disaster event of interest. Accordingly, modeling choices for exploring pre-disaster social vulnerability to earthquake might differ from those for post-event social vulnerability to typhoon. For this study, we used previous case study findings to guide development of a social vulnerability index tailored to flood recovery, and explore the relationship between social vulnerability and property acquisitions. The overriding goal was to create an index that balanced a theoretically and empirically grounded understanding of social vulnerability in flood recovery, with the statistical and methodological tenets of index construction.

\subsection{Identifying social vulnerability determinants}

Qualitative and empirical case studies offer detailed understanding of social vulnerability determinants that is often not reflected in quantitative social vulnerability indicators. To tailor the Cedar Rapids indicators to flood recovery, we employed the findings of a companion meta-analysis of flood disaster case studies (Rufat et al. 2015). The research culled an original selection of 125 articles involving social vulnerability to floods, removing those focused physical flood processes, built environment impacts, disaster management, climate change, multi-hazard vulnerability, indicator construction, and computer modeling. The overarching goal was to identify studies that examined the 
processes and determinants that led to increased social vulnerability outcomes in flood disasters, as opposed to studies that simply included social vulnerability indicators. Based on these criteria, Rufat et al. (2015) identified sixty-seven empirical case studies, which we further winnowed in this research to only include those focused on the recovery stage from floods in more developed national settings. A total of twenty-three articles remained, comprised of studies from the US and Western Europe (Table 6).

To quantify the determinants, demographic data from the US Census 2000 dataset were acquired at the block group scale, for areas within Cedar Rapids. The block group level of aggregation is the finest spatial resolution for which census socioeconomic data are collected. Overall, the 2008 floodplain spanned a total of 30 census block groups. The 2000 decennial census was employed because it is the most complete demographic dataset that precedes the 2008 flood. Implicit in this choice is the (potentially flawed) assumption that no major socio-demographic shifts occurred between 2000 and the flood of 2008. As an alternative, we considered using census demographic estimates from the more timely American Community Survey (ACS) 2005-2009 release. However, ACS estimates at the census block group scale are based on a much lower sample size than the decennial census. This results in a high margin of error that makes the ACS estimates unreliable for many variables (Spielman et al. 2014).

Table 4 Social vulnerability indicators for flood recovery in Cedar Rapids

\begin{tabular}{|c|c|c|c|c|}
\hline Indicator & Rationale & $\begin{array}{l}\text { Flooded } \\
\text { areas }(\%)\end{array}$ & $\begin{array}{l}\text { Non- } \\
\text { flooded } \\
\text { areas }(\%)\end{array}$ & $\begin{array}{l}\text { Article } \\
\text { count }\end{array}$ \\
\hline Poverty & $\begin{array}{l}\text { Lower savings and insurance, home repair } \\
\text { difficulties, negative physical and mental health } \\
\text { outcomes, greater displacement }\end{array}$ & 10.9 & 5.7 & 11 \\
\hline Black & Lower social capital, lack of trust in government & 3.6 & 3.2 & 9 \\
\hline Renters & $\begin{array}{l}\text { Lack of control over home repair, less insurance, } \\
\text { relief policies favor homeowners }\end{array}$ & 34.1 & 28.3 & 8 \\
\hline Elderly & $\begin{array}{l}\text { Negative health outcomes, lower ability to navigate } \\
\text { insurance claims, increased social isolation }\end{array}$ & 16.0 & 16.8 & 8 \\
\hline Children & $\begin{array}{l}\text { Negative psychological outcomes, susceptibility to } \\
\text { indoor mold }\end{array}$ & 23.8 & 24.8 & 7 \\
\hline Unemployed & Difficulty returning to home & 3.5 & 2.4 & 5 \\
\hline $\begin{array}{l}\text { Linguistic } \\
\text { isolation }\end{array}$ & Impedes access to information and assistance & 0.9 & 0.7 & 4 \\
\hline Disabled & Social isolation & 19.2 & 14.7 & 3 \\
\hline $\begin{array}{l}\text { Low } \\
\text { educational } \\
\text { attainment }\end{array}$ & $\begin{array}{l}\text { Increased difficulties with insurance and assistance } \\
\text { claims }\end{array}$ & 14.5 & 7.7 & 3 \\
\hline $\begin{array}{l}\text { Female- } \\
\text { headed } \\
\text { household }\end{array}$ & $\begin{array}{l}\text { Less emotional support, additional care } \\
\text { responsibilities }\end{array}$ & 11.5 & 8.8 & 3 \\
\hline Hispanic & Lower assistance-to-damage ratios & 1.9 & 1.5 & 3 \\
\hline $\begin{array}{l}\text { No vehicle } \\
\text { access }\end{array}$ & Increased isolation & 9.1 & 6.0 & 1 \\
\hline
\end{tabular}




\subsection{Indicator selection}

The first step in the index construction was to connect census variables with the determinants of social vulnerability from the meta-analysis. Data availability emerged as a constraint for social vulnerability dimensions of risk perception, health, and social capital, which have limited or nonexistent coverage in the census data. This resulted in removal of three of the case studies (Carroll et al. 2009; Hawkins and Maurer 2010; Werg et al. 2013). The census data that could be linked with social vulnerability determinants primarily consist of indicators of socioeconomic status and demographic characteristics. We discarded two indicators identified by the meta-analysis, Asian and Female, following consultation with two local non-profit organizations serving vulnerable populations during the flood recovery. At the conclusion of this process, twelve indicators of social vulnerability in flood recovery remained (Table 4). Table 6 (Appendix) lists the 23 case studies and the social vulnerability indicators associated with each.

Using the census data, the population counts for each of the twelve indicators were tallied for the 2008 flooded and non-flooded areas and are expressed in Table 4 as percentages. A comparison of these two zones shows that the proportions are greater in flooded areas for most of the indicators, suggesting a heightened flood impact on vulnerable populations. The largest disparities were found for indicators of educational attainment, renters, poverty, and disability.

\subsection{Index structure}

The use of flood disaster case studies as the basis for indicator selection improves the conceptual validity of the index, but provides little insight as to how the indicators within

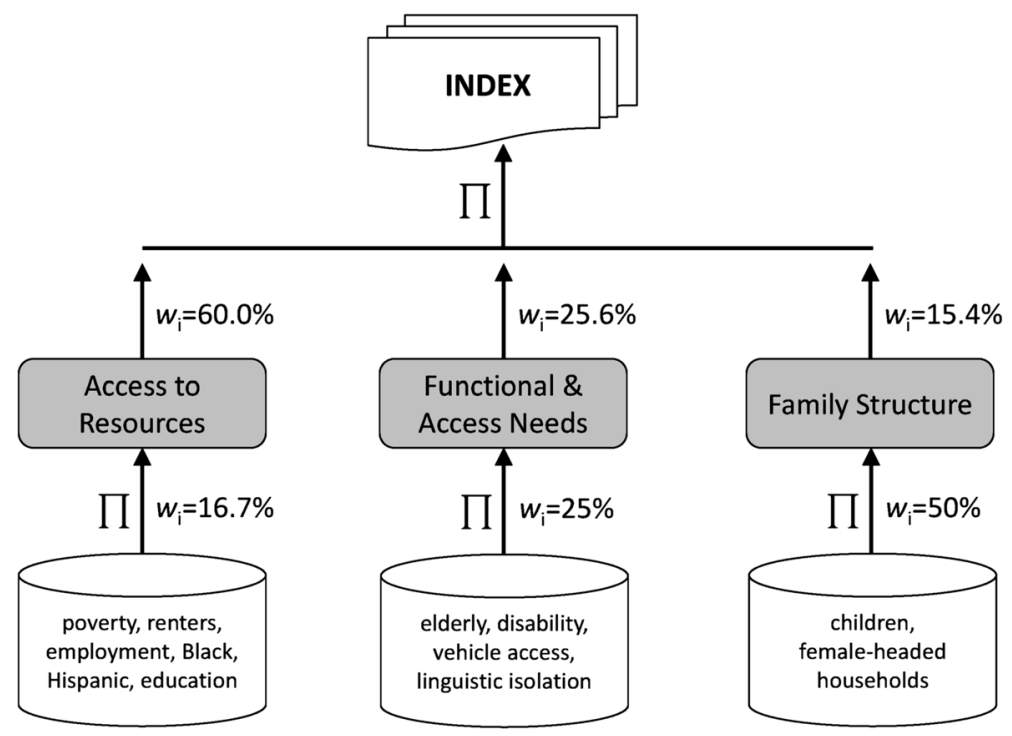

Fig. 4 Social vulnerability index structure 
the index should be structured, weighted, or aggregated. Typical structural approaches employed in social vulnerability indices have included aggregations of single indicators (Lein and Abel 2010), hierarchical organization using thematic pillars (Mustafa et al. 2011; Tate 2013), and the use of factor analysis to identify latent variables (Kaźmierczak and Cavan 2011; Yoon 2012). We applied a hierarchical model, organized into three themes: access to resources, functional and access needs, and family structure.

Access to resources concerns the ease of residents to access various financial and human resources, and the legal, political, and institutional barriers to doing so. The indicators assigned to this pillar include poverty, education, unemployment, race, ethnicity, and renters. Functional and access needs refers to populations with additional needs related to supervision, mobility, transportation, communication, and medical care. The indicators of linguistic isolation, elderly, vehicle access, and disability were assigned to this second pillar. The third pillar of family structure denotes the roles and needs associated with household composition and includes the indicators of children and female-headed households. The hierarchical structure for the social vulnerability index is illustrated in Fig. 4.

\subsection{Weighting}

In addition to index structure and indicator selection, weighting and aggregation are also key stages of index construction (OECD 2008). Ideally, indicator weights should be strongly linked to a conceptual framework and reflect their relative importance to social vulnerability (Jones and Andrey 2007). As changes in weighting approach can significantly influence output vulnerability index scores (Tate 2012), it is important for index developers to carefully consider the weighting method. Differential weighting approaches applied in previous studies include statistical (Rygel et al. 2006; Bjarnadottir et al. 2011), expert (Brooks et al. 2005; Emrich 2005), author judgment (Mustafa et al. 2011; Vincent 2004), and stakeholder participation (Oulahen et al. 2015). But consistent schema for differential weighting have yet to emerge (Lein and Abel 2010), and equal weights remain the predominant methodological approach. However, there is no conceptual or empirical reason to believe that the determinants of social vulnerability contribute equally to social vulnerability (Vincent 2004).

For this study, we applied a new approach for indicator weights, based on the results of the meta-analysis. The rationale is that through examining the findings of empirical case studies with a similar social vulnerability context, greater understanding about the relative influence of social vulnerability determinants can be gleaned. As a result, we tallied each indicator when it appeared in a case study as a driver of social vulnerability, and used the resulting counts to compute the frequency of occurrence of each indicator. This frequency metric was then applied to define differential weights in the index. The counts are shown in Table 4, with the indicators are sorted by frequency.

The results suggest that the social vulnerability dimensions of poverty, race, land tenure, and age have outsized importance during the recovery phase from flooding. To translate these rankings into explicit weights, the count of articles for indicators in each pillar is divided by the total count for all indicators (65). For example, this produced a weight of $15.4 \%$ for the family structure pillar $(7 / 65+3 / 65)$, based on a sum of article counts for the variables of children and female-headed households. The weights determined for each pillar are shown on Fig. 4. 


\subsection{Aggregation}

An aggregation methodology was required to combine the normalized and weighted indicators into pillars, and the pillars into the hierarchical index. Indices of social vulnerability to hazards tend to apply the additive methods (Jones and Andrey 2007), such as the arithmetic mean. However, additive aggregation schemes are incapable of reflecting interactions between indicators that case study literature has clearly shown to exist. For example, Elliott and Pais (2006) found that specifically low-income Black residents, not the poor or Blacks in general, were particularly vulnerable during evacuation from Hurricane Katrina. The use of additive aggregation in this case would misrepresent the underlying social vulnerability processes. Additive aggregation also has the undesirable property of compensability, in which the effect of low values in one indicator can be fully offset by high values in another (Noble et al. 2006; Fekete 2012). However, there is no theoretical or empirical basis to assume that dimensions of social vulnerability are so easily substitutable. To better account for interaction and compensability effects, we aggregated indicators using the weighted geometric mean (OECD 2008). Equal weighting was applied for aggregation to the pillar level, and differential weights were used to aggregate the four pillars to the index level. The resulting index scores were normalized using min-max scaling, so that the final index ranged from 1 to 100 . Table 5 shows the resulting correlations between the index and its pillars.

The use of highly correlated pillars in an index can introduce implicit weights that rival the influence of explicit weights (Paruolo et al. 2013). As general rules of thumb, correlations between each pillar and the index should fall in the range of 0.4-0.8, and the pillars should be positively correlated with one another (Saisana 2009). This ensures that the pillars and index statistically point in the same direction, while allowing for a limited degree of overlap between pillars. For our social vulnerability index for flood recovery, the correlations deviate only mildly from these ideal conditions, with the pillars representing distinct, yet complimentary vulnerability dimensions.

\section{Social equity in property acquisitions}

Given the LMI criteria for CDBG qualification, socially vulnerable areas might be expected to be associated with more buyouts. The social vulnerability index for flood recovery can be used to assess this proposition. Theoretically, places with higher social vulnerability should be associated with greater disaster impacts. But it matters how those impacts are measured. Assessing impact via total economic loss is problematic because it favors places with higher property values (Gall et al. 2011). For this reason, the use of total buyout costs as a comparison metric with social vulnerability is unsuitable.

Table 5 Spearman correlations for the index and pillars

\begin{tabular}{llll}
\hline & Resource access & Functional needs & Family structure \\
\hline Index & 0.88 & 0.75 & 0.55 \\
Functional needs & 0.44 & & \\
Family structure & 0.55 & $0.25^{*}$ & \\
\hline
\end{tabular}

* Coefficient is not significant at the 0.05 level 
What is needed is a way to measure the impact of a loss of a property, relative to the coping capacity of the owners to absorb it. The same monetary loss suffered by a wellresourced household and a socially vulnerable household is likely to have a disparate relative impact. Hence, the acquisition costs were adjusted by income to develop a relative loss metric. To do so, we first computed the average buyout cost per census block group. This was done to express the buyout costs (parcel level) at the same geographic scale as the census data used for the social vulnerability index. The average buyout cost was then normalized by the median income of the block group to compute the relative loss metric.

If the voluntary acquisition program truly targets socially disadvantaged neighborhoods, areas with high relative loss should coincide with areas of high social vulnerability. This is particularly relevant for acquisitions financed by CDBG, whose principal goal is neighborhood revitalization in socioeconomically depressed areas. As such, we correlated the relative loss metric with the social vulnerability index to assess the social equity of the distribution of buyout expenditures. The index was developed for the thirty census block groups in the 2008 floodplain, but ten were removed from the analysis because they contained no acquired properties. One other block group contained a very high value commercial property and was removed according to the outlier labeling rule (Hoaglin and Iglewicz 1987). The distributions of the social vulnerability index and relative loss metric for the remaining nineteen census blocks were tested for normality using the Shapiro-Wilk test, and the null hypothesis was rejected. Hence, the parametric Spearman correlation coefficient was used to test the relationship between the two datasets. The result $\left(r_{\mathrm{s}}=0.657, p<0.01\right)$ indicates a moderately strong and positive association. Figure 5 illustrates the relationship between the relative loss metric and social vulnerability index score.

The level of agreement between the index and relative cost ratio suggests that property acquisition program indeed targeted the most socially vulnerable neighborhoods. This can be seen as a positive in terms of equity in the distribution of property acquisition resources. Many of the properties in the Neighborhood Revitalization Area are slated for redevelopment with affordable housing based on environmentally sustainable designs. However,

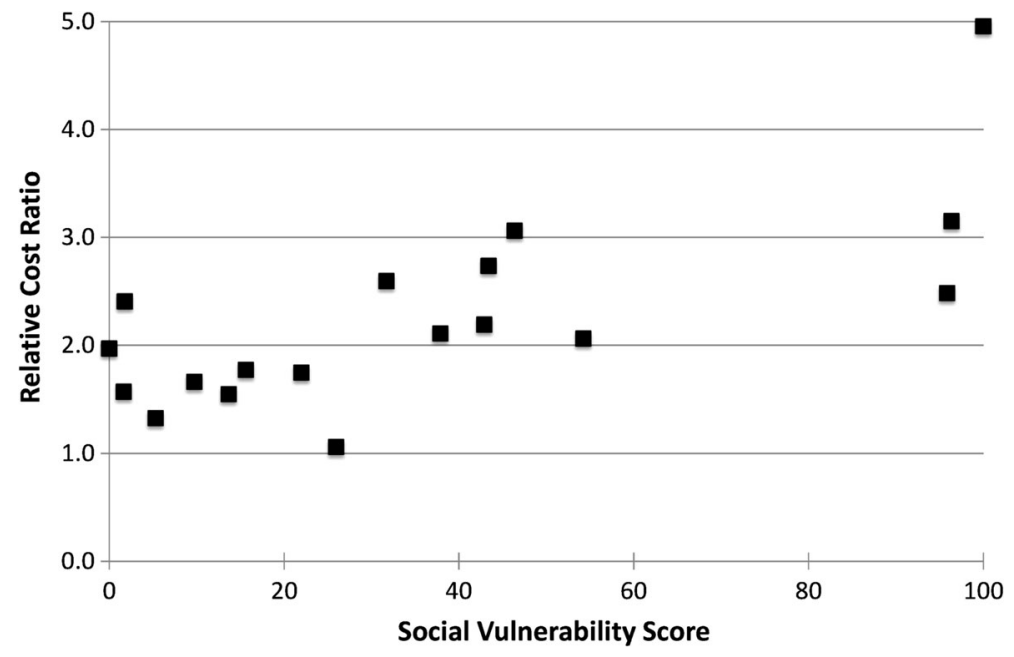

Fig. 5 Relative loss ratio versus social vulnerability 
the buyouts also can be viewed in terms of resident displacement and loss of neighborhood cohesion that disproportionately affected socially vulnerable areas. Based on conversations with city residents and officials, it is not entirely clear where the displaced residents went.

\section{Discussion and conclusions}

\subsection{Benefit-cost analysis}

There are two criteria governing the eligibility of HMGP funds for property acquisition following a Presidential Disaster Declaration: (1) The property is within the 100-year floodplain and receives "substantial damage" or (2) the benefit-cost ratio of future avoided damage is greater than unity. There is a considerable capacity to absorb even fairly extreme events in Cedar Rapids without overtopping the stream banks. However, the mild topographical slope of the floodplain outside of the stream banks means that if the banks are overtopped, the areal extent of damage will be quite large. Topography plays an important role in how quickly damage increases with peak stream flow. If the topography is relatively flat, the areal extent of damage will rise dramatically once the stream banks have been breached. As the slope increases, damage extent is mitigated simply by the topography, and the area inundated will be small given a fixed stream flow.

The morphology of the river channel and flood barriers in Cedar Rapids largely protect the city for flood stages $<21.5$ feet, but the potential for discontinuities in the flow-damage curve increases when barriers are overtopped or breached. This is an important point for Cedar Rapids, because damage rises dramatically once the river stage exceeds 21.5 feet, a flood stage that had never been reached prior to the 2008 flood. Since the flood, Cedar Rapids has updated their plans for flood protection. The new plans call for protection to the 2008 flood stage with a freeboard of 3-4 feet on the east side of the river (City of Cedar Rapids 2015a), and to the 2008 flood stage on the west side (City of Cedar Rapids 2015b). Based on the results of the benefit-cost analysis, protecting to the 24-foot flood stage may be advised, but going beyond such protection may not be unless events such as 2008 become more frequent.

However, the benefit-cost analysis focuses on avoided private losses and not losses as a whole that would include public environmental and infrastructure. A major critique of benefit-cost analysis for flood mitigation is that it purports to be forward looking in avoided losses, yet uses a historical perspective in doing so-the data used to calculate expected future flood probabilities are based on historical stream flows (Shreve and Kelman 2014). As shown by Villarini and Strong (2014) for a different Iowa watershed, changes in precipitation and land use have the potential to drastically change the probability distribution of annual peak discharge. Flood frequency analysis assumes stationarity (Merz and Thieken 2009), so if changes in precipitation or land use cause a change in the distribution of peak stream flows, the AAL calculations will also change. To account for non-stationarity, the peak flow distribution would need to be derived from downscaled climate and land use change models together with hydrologic models. In most situations, this will be outside of the scope of the analysis and introduce even larger bounds on the uncertainty of the estimates of AAL. In the case of Cedar Rapids, this is not a major concern unless discharge values approximating those of the 2008 flood become more typical, and not extreme as suggested by the historical data. 
The focus of our citywide analysis of direct losses to buildings and contents differs in several respects from methods embedded in the FEMA BCA Toolkit for individual buildings. The approach taken here for the estimation of the benefits of the buyout program only considers the dwelling and improvement damage avoided. To be more consistent with FEMA's BCA tool, environmental benefits (e.g., flood storage, recreation, aesthetics) avoided maintenance and displacement costs, and better first-floor-height data would also need to be included. Still, the conservative nature of the estimates together with the fact that a vast majority of the parcels in the Greenway and Construction Areas have a benefitcost ratio of greater than unity, justifies the use of the buyout program for hazard mitigation in the City of Cedar Rapids. Adding these additional benefits would only strengthen the argument for such an instrument.

\subsection{Social vulnerability in the flood recovery context}

The application of meta-analysis to both the selection of indicators and determination of weights is an attempt to break with orthodoxy of context-independent indicators and equal weighting. This approach, however, is not without faults. In addition to the indicators shown in Table 4, the meta-analysis found that risk perception, mental and physical health, and social capital are also important social vulnerability dimensions during flood recovery. However, they were not explicitly included in the indicator set due to lack of data availability. With respect to weights, the case study frequencies on which they are based could be biased by the choices of study area, conditions, and approaches by the authors. But despite these potential flaws, the meta-analysis approach provides empirical grounding for indicator selection and differential weights at a time when many studies using social vulnerability indicators rely on ad hoc modeling decisions.

Linking the meta-analysis results to the index construction process also helps reduce epistemic uncertainty in the index. Epistemic uncertainty in models arises due to lack of knowledge and data describing the system of interest (Kiureghian and Ditlevsen 2009). For social vulnerability indices, such knowledge uncertainties are especially relevant to modeling decisions regarding indicator selection, weighting, and aggregation. Particularly when the stakes are high for decisions using indicators, sensitivity analysis should be an element of the index construction process because it helps identify input data and modeling choices that have disproportionate influence on the index (Kienberger and Hagenlocher 2014; Tate 2012). But even in the absence of sensitivity analysis, when indicator construction is tied to well-defined theoretical, empirical, and statistical rationales, epistemic uncertainties are reduced and reliability of the index increased.

More reliable social vulnerability metrics are key if such indicators are to achieve the aims for which they are touted, including identification of vulnerable populations, raising awareness, and resource allocation (Hinkel 2011). Moreover, if social equity is to be reflected in policy for post-disaster recovery and pre-disaster planning, reliable vulnerability indicators are needed for policy evaluation. Just as the benefit-cost ratio has assumed a central role in project evaluation of economic viability, well-constructed social vulnerability indicators have the potential to do the same in the assessment of social equity in disaster policy.

\subsection{Disaster recovery policy}

The Cedar Rapids 2008 flood provides an opportunity to broadly evaluate property acquisition programs from a policy perspective. The flood impacts revealed inadequacies 
in pre-disaster planning and possibilistic decision-making (Clarke 2005) with respect to worst-case flooding scenarios in Cedar Rapids. Strengthening integration of mitigation into local development regulations, zoning, and enforcement is important for addressing these gaps. However, adoption of many proactive measures (e.g., retrofitting essential facilities, elevating structures, acquiring properties) is constrained by the limited local, state, and federal resources available for pre-disaster mitigation activities. Federal funding is often necessary to implement projects that would otherwise be cost prohibitive or politically infeasible for local governments. However, the bulk of federal assistance becomes available only in the aftermath of a disaster. An example of proactive policy would be to increase funding and eligibility for pre-disaster mitigation activities outside of the Presidential Disaster Declaration process.

The LMI provisions of CDBG make it the more likely program to result in socially equitable distribution of disaster recovery resources. Through their "ROOTs" program in the Neighborhood Revitalization Area, Cedar Rapids has partnered with local developers to build new affordable housing available to buyers with household incomes below $100 \%$ of the area median. The construction follows environmentally sustainable designs, and buyers are eligible for down payment assistance. However, properties acquired through CDBG require neither a benefit-cost analysis nor a mitigation objective. This is because the economic revitalization mission of the program was not originally designed to operate in disaster recovery. Redevelopment can occur on properties acquired by CDBG, potentially reintroducing risk and loss potential outside the 100-year floodplain where a substantial proportion of flood insurance claims occur (Highfield et al. 2013). CDBG policy should include provisions that disincentivize full restoration or intensification of development in flood-damaged areas.

The benefit-cost provisions of HMGP make it the program more likely to result in economically viable resource spending. HMGP property acquisition might be a preferred tool for communities if policies were amended to allow for more flexibility with respect to future use of acquired properties, as well as allowing for better integration into an overall community plan and flood mitigation strategy. The 2008 Cedar Rapids flood provides an example of how the rigidity of HMGP impacts local decision-making: Nearly half of the CDBG buyouts were for properties within the 100-year floodplain, but they were ineligible for HMGP funding because the planned levee construction conflicted with HMGP deed restrictions.

The two federal programs available for property acquisition follow distinct objectives. CDBG promotes neighborhood revitalization and accounts for vulnerable populations, but it is only modestly focused on mitigation and funds may flow slowly (if at all) to communities because they require special Congressional appropriation. HMGP mitigates risk by restricting future land use, but has limited flexibility for community planning. The contrasting objectives effectively compel communities to pick and choose funding programs despite basic principles of mitigation. A more holistic policy approach would integrate the two objectives around sound planning and decision-making.

Acknowledgments This research has been supported by grants from the US National Science Foundation (Award \#1333190) and the University of Iowa Water Sustainability Initiative. We would like to thank the City of Cedar Rapids for sharing geospatial buyout and property data, and the Iowa Flood Center for use of modeled flood depth grids.

Open Access This article is distributed under the terms of the Creative Commons Attribution 4.0 International License (http://creativecommons.org/licenses/by/4.0/), which permits unrestricted use, distribution, 
and reproduction in any medium, provided you give appropriate credit to the original author(s) and the source, provide a link to the Creative Commons license, and indicate if changes were made.

\section{Appendix}

See Table 6.

Table 6 Previous studies and associated social vulnerability indicators

\begin{tabular}{|c|c|c|c|}
\hline $\begin{array}{l}\text { Study } \\
\text { ID }\end{array}$ & Study & Indicator & $\begin{array}{l}\text { IDs of studies that included the } \\
\text { indicator }\end{array}$ \\
\hline 1 & Ahern et al. (2005) & Poverty & $2,4,5,6,7,9,13,14,16,19,20$ \\
\hline 2 & Alderman et al. (2012) & Black & $2,5,6,7,8,9,11,13,16$ \\
\hline 3 & Carroll et al. (2010) & Renters & $7,8,9,11,12,13,19,20$ \\
\hline 4 & Chen et al. (2007) & Elderly & $2,5,9,10,12,14,17,20$ \\
\hline 5 & Collins et al. (2013) & Children & $1,2,14,15,17,19,20$ \\
\hline 6 & Colten (2006) & Unemployed & $7,9,13,19,20$ \\
\hline 7 & Elliott and Pais (2006) & Linguistic isolation & $4,5,14,18$ \\
\hline 8 & Elliott et al. (2009) & Disabled & $2,12,20$ \\
\hline 9 & Green et al. (2007) & $\begin{array}{l}\text { Low educational } \\
\text { attainment }\end{array}$ & $3,14,20$ \\
\hline 10 & Jonkman et al. (2009) & $\begin{array}{l}\text { Female-headed } \\
\text { household }\end{array}$ & $2,19,20$ \\
\hline 11 & Kamel (2012) & Hispanic & $5,11,14$ \\
\hline 12 & Kuhlicke et al. (2011) & No vehicle access & 20 \\
\hline 13 & Logan (2006) & Asian ${ }^{b}$ & 4,11 \\
\hline 14 & Lowe et al. (2013) & Female $^{\mathrm{b}}$ & $1,2,7,12,14,15,20$ \\
\hline 15 & Mason et al. (2010) & & \\
\hline 16 & Masozera et al. (2007) & & \\
\hline 17 & Stanke et al. (2012) & & \\
\hline 18 & $\begin{array}{l}\text { Vu and VanLandingham } \\
\text { (2012) }\end{array}$ & & \\
\hline 19 & Walker et al. (2012) & & \\
\hline 20 & Whittle et al. (2010) & & \\
\hline $21^{\mathrm{a}}$ & Carroll et al. (2009) & & \\
\hline $22^{\mathrm{a}}$ & Hawkins and Maurer (2010) & & \\
\hline $23^{\mathrm{a}}$ & Werg et al. (2013) & & \\
\hline
\end{tabular}

${ }^{a}$ Case study removed because associated social vulnerability indicators absent in census data

b Indicator removed following consultation with local non-profit organizations

\section{References}

Ahern M, Kovats RS, Wilkinson P, Few R, Matthies F (2005) Global health impacts of floods: epidemiologic evidence. Epidemiol Rev 27(1):36-46

Alderman K, Turner LR, Tong S (2012) Floods and human health: a systematic review. Environ Int $47: 37-47$ 
Bjarnadottir S, Li Y, Stewart MG (2011) Social vulnerability index for coastal communities at risk to hurricane hazard and a changing climate. Nat Hazards 59(2):1055-1075

Boyd E (2011) Community Development Block Grant funds in disaster relief and recovery. Congressional Research Service, Washington, DC

Brooks N, Adger NW, Kelly MP (2005) The determinants of vulnerability and adaptive capacity at the national level and the implications for adaptation. Glob Environ Change 15(2):151-163

Carroll B, Morbey H, Balogh R, Araoz G (2009) Flooded homes, broken bonds, the meaning of home, psychological processes and their impact on psychological health in a disaster. Health Place 15(2):540-547

Carroll B, Balogh R, Morbey H, Araoz G (2010) Health and social impacts of a flood disaster: responding to needs and implications for practice. Disasters 34(4):1045-1063

Chen A, Keith V, Leong K, Airriess C, Li W, Chung K, Lee C (2007) Hurricane Katrina: prior trauma, poverty and health among Vietnamese-American survivors. Int Nurs Rev 54(4):324-331

City of Cedar Rapids (2010) Other social effects report: City of Cedar Rapids, Iowa-Flood of 2008

City of Cedar Rapids (2014) Cedar Rapids greenways. http://www.cedar-rapids.org/resident-resources/ parks-recreation/parks/pages/cedar-rapids-greenways.aspx. Accessed 4 Oct 2014

City of Cedar Rapids (2015a) East side flood protection. http://www.cedar-rapids.org/city-news/floodrecovery-progress/floodmanagementsystem/pages/eastsidefloodprotection.aspx. Accessed 20 July 2015

City of Cedar Rapids (2015b) West side flood protection. http://www.cedar-rapids.org/city-news/floodrecovery-progress/floodmanagementsystem/pages/westsidefloodprotection.aspx. Accessed 20 July 2015

Clarke L (2005) Worst-case thinking: an idea whose time has come. Nat Hazards Obs 29(3):1-3

Collins TW, Jimenez AM, Grineski SE (2013) Hispanic health disparities after a flood disaster: results of a population-based survey of individuals experiencing home site damage in El Paso (Texas, USA). J Immigr Minor Health 15(2):415-426

Colten CE (2006) Vulnerability and place: flat land and uneven risk in New Orleans. Am Anthropol 108(4):731-734

Conrad DR, McNitt B, Stout M (1998) Higher ground: a report on voluntary property buyouts in the nation's floodplains. National Wildlife Federation, Washington, DC

Cutter SL, Boruff BJ, Shirley WL (2003) Social vulnerability to environmental hazards. Soc Sci Q 84(1):242-261

de Vries DH, Fraser JC (2012) Citizenship rights and voluntary decision making in post-disaster US floodplain buyout mitigation programs. Int J Mass Emerg Disasters 30(1):1-33

Ding A, White JF, Ullman PW, Fashokun AO (2008) Evaluation of HAZUS-MH flood model with local data and other program. Nat Hazards Rev 9:20-28

Elliott JR, Pais J (2006) Race, class, and Hurricane Katrina: social differences in human responses to disaster. Soc Sci Res 35(2):295-321

Elliott JR, Bellone Hite A, Devine JA (2009) Unequal return: the uneven resettlements of new orleans' uptown neighborhoods. Organ Environ 22(4):410-421

Emrich CT (2005) Social vulnerability in US metropolitan areas: improvements in hazard vulnerability assessment. University of South Carolina, Columbia

Fekete A (2012) Spatial disaster vulnerability and risk assessments: challenges in their quality and acceptance. Nat Hazards 61(3):1161-1178

FEMA (2003) HAZUS-MH technical manual. Federal Emergency Management Agency, Washington, DC

FEMA (2010) Flood insurance rate map: Linn County, Iowa and incorporated areas. Vol Flood Insurance Study Number 19113CV001A, Flood Insurance Study Number 19113CV001A edn. National Flood Insurance Program

FEMA (2013) Hazard mitigation assistance unified guidance: hazard mitigation grant program, pre-disaster mitigation program, and flood mitigation assistance program. U.S. Federal Emergency Management Agency

Fraser J, Elmore R, Godschalk D, Rohe W (2003) Implementing floodplain land acquisition programs in urban localities. The Center for Urban and Regional Studies, University of North Carolina at Chapel Hill, Chapel Hill, NC

Gall M, Borden KA, Emrich CT, Cutter SL (2011) The unsustainable trend of natural hazard losses in the United States. Sustainability 3:2157-2181. doi:10.3390/su3112157

Gotham KF (2014) Reinforcing inequalities: the impact of the CDBG program on post-Katrina rebuilding. Hous Policy Debate 24(1):192-212

Green R, Bates LK, Smyth A (2007) Impediments to recovery in New Orleans' upper and lower ninth ward: one year after Hurricane Katrina. Disasters 31(4):311-335 
Hawkins RL, Maurer K (2010) Bonding, bridging and linking: how social capital operated in New Orleans following Hurricane Katrina. Br J Soc Work 40(6):1777-1793

Highfield WE, Norman SA, Brody SD (2013) Examining the 100-year floodplain as a metric of risk, loss, and household adjustment. Risk Anal 33(2):186-191

Hinkel J (2011) "Indicators of vulnerability and adaptive capacity": towards a clarification of the sciencepolicy interface. Glob Environ Change 21(1):198-208. doi:10.1016/j.gloenvcha.2010.08.002

Hoaglin DC, Iglewicz B (1987) Fine-tuning some resistant rules for outlier labeling. J Am Stat Assoc 82(400): 1147-1149

HUD (2014a) "Basically CDBG" course training manual: chapter 3-national objectives. U.S. Department of Housing and Urban Development (HUD). http://portal.hud.gov/hudportal/HUD?src=/program offices/comm_planning/communitydevelopment/training/basicallycdbg. Accessed 4 Oct 2014

HUD (2014b) CDBG disaster recovery assistance. U.S. Department of Housing and Urban Development (HUD). http://portal.hud.gov/hudportal/HUD?src=/program_offices/comm_planning/communitydevelopment/progr ams/drsi. Accessed 1 Sep 2014

Interagency Floodplain Management Review Committee (1994) Sharing the challenge: floodplain management into the 21 st century. US Government Printing Office, Washington, DC

Johnson C, Penning-Roswell E, Parker D (2007) Natural and imposed injustices: the challenges in implementing 'fair' flood risk management policy in England. Geogr J 173(4):374-390

Jones B, Andrey J (2007) Vulnerability index construction: methodological choices and their influence on identifying vulnerable neighborhoods. Int J Emerg Manage 4(2):269-295

Jonkman SN, Maaskant B, Boyd E, Levitan ML (2009) Loss of life caused by the flooding of New Orleans after Hurricane Katrina: analysis of the relationship between flood characteristics and mortality. Risk Anal 29(5):676-698

Kamel N (2012) Social marginalisation, federal assistance and repopulation patterns in the New Orleans metropolitan area following Hurricane Katrina. Urban Stud 49(14):3211-3231

Kaźmierczak A, Cavan G (2011) Surface water flooding risk to urban communities: analysis of vulnerability, hazard and exposure. Landsc Urban Plan 103(2):185-197. doi:10.1016/j.landurbplan.2011.07. 008

Kienberger S, Hagenlocher M (2014) Spatial-explicit modeling of social vulnerability to malaria in East Africa. Int J Health Geogr 13(1):29

Kiureghian AD, Ditlevsen O (2009) Aleatory or epistemic? Does it matter? Struct Saf 31(2):105-112. doi:10.1016/j.strusafe.2008.06.020

Krajewski WF, Mantilla R (2010) Why were the 2008 floods so large? In: Mutel CF (ed) A watershed year: anatomy of the Iowa floods of 2008. University of Iowa Press, Iowa City, pp 19-30

Kuhlicke C, Scolobig A, Tapsell S, Steinführer A, De Marchi B (2011) Contextualizing social vulnerability: findings from case studies across Europe. Nat Hazards 58(2):789-810. doi:10.1007/s11069-011-9751-6

Lein JK, Abel LE (2010) Hazard vulnerability assessment: how well does nature follow our rules? Environ Hazards 9(2):147-166

Logan JR (2006) The impact of Katrina: race and class in storm-damaged neighborhoods. Brown University, Providence, $\mathrm{p} 16$

Lowe D, Ebi KL, Forsberg B (2013) Factors increasing vulnerability to health effects before, during and after Floods. Int J Environ Res Public Health 10(12):7015-7067

Mason V, Andrews H, Upton D (2010) The psychological impact of exposure to floods. Psychol Health Med 15(1):61-73

Masozera M, Bailey M, Kerchner C (2007) Distribution of impacts of natural disasters across income groups: a case study of New Orleans. Ecol Econ 63(2):299-306

Merz B, Thieken AH (2009) Flood risk curves and uncertainty bounds. Nat Hazards 51(3):437-458

Messner F, Penning-Rowsell E, Green C, Meyer V, Tunstall S, van der Veen A (2007) Evaluating flood damages: guidance and recommendations on principles and methods. FLOODsite-Report T09-06$01: 176$

Mustafa D, Ahmed S, Saroch E, Bell H (2011) Pinning down vulnerability: from narratives to numbers. Disasters 35(1):62-86. doi:10.1111/j.0361-3666.2010.01193.x

NOAA (2015) Billion-dollar weather and climate disasters. National Oceanic and Atmospheric Administration. https://www.ncdc.noaa.gov/billions/events. Accessed 15 July 2015

Noble M, Wright G, Smith G, Dibben C (2006) Measuring multiple deprivation at the small-area level. Environ Plan A 38(1):169-185

OECD (2008) Handbook on constructing composite indicators: methodology and user's guide. Organization for Economic Co-operation and Development, Paris

OMB (2013) Circular A-94 appendix C. White House Office of Management and Budget. http://www. whitehouse.gov/omb/circulars_a094/a94_appx-c. Accessed 15 Oct 2014 
Oulahen G, Mortsch L, Tang K, Harford D (2015) Unequal vulnerability to flood hazards: "ground truthing" a social vulnerability index of five municipalities in Metro Vancouver, Canada. Ann Assoc Am Geogr 105(3):473-495

Paruolo P, Saisana M, Saltelli A (2013) Ratings and rankings: voodoo or science? J R Stat Soc: Ser A (Stat Soc) 176(3):609-634. doi:10.1111/j.1467-985X.2012.01059.x

Peak Streamflow for the Nation: USGS 05464500 Cedar River at Cedar Rapids, IA (2014). U.S. Geological Survey. http://nwis.waterdata.usgs.gov/usa/nwis/peak/?site_no=05464500. Accessed 30 Aug 2014

Peoples Weather Map (2015) Flood of 1929: Williams and Hunting Company. http://peoplesweathermap. org/index.php/home/story/linn/WH. Accessed 19 July 2015

Phillips B, Thomas D, Fothergill A, Blinn-Pike L (2010) Social vulnerability to disasters. CRC Press, Boca Raton

Rufat S, Tate E, Burton CG, Maroof AS (2015) Social vulnerability to floods: review of case studies and implications for measurement. Int J Disaster Risk Reduct. doi:10.1016/j.ijdrr.2015.09.013

Rygel L, O'Sullivan D, Yarnal B (2006) A method for constructing a social vulnerability index: an application to hurricane storm surges in a developed country. Mitig Adapt Strateg Glob Change 11(3):741-764

Saisana M (2009) Internal consistency checks in the development of composite indicators and some rules of thumb. Training: constructing composite indicators-theoretical and Practical aspects, Luxembourg, 22-23 September 2009. European Commission Joint Research Centre, Ispra, Italy

Scawthorn C, Blais N, Seligson H, Tate E, Mifflin E, Thomas W, Murphy J, Jones C (2006a) HAZUS-MH flood loss estimation methodology. I: overview and flood hazard characterization. Nat Hazards Rev 7(2):60-71

Scawthorn C, Flores P, Blais N, Seligson H, Tate E, Chang S, Mifflin E, Thomas W, Murphy J, Jones C, Lawrence M (2006b) HAZUS-MH flood loss estimation methodology. II. Damage and loss assessment. Nat Hazards Rev 7(2):72-81

Schulze WD, Kneese AV (1981) Risk in benefit-cost analysis. Risk Anal 1(1):81-88. doi:10.1111/j.15396924.1981.tb01362.x

Shreve C, Kelman I (2014) Does mitigation save? Reviewing cost-benefit analyses of disaster risk reduction. Int J Disaster Risk Reduct 10:213-235

Smith R (2014) Cedar Rapids flood buyout is history: five years, 1,356 property purchases later. Cedar Rapids, The Gazette

Spader J, Turnham J (2014) CDBG disaster recovery assistance and homeowners' rebuilding outcomes following Hurricanes Katrina and Rita. Hous Policy Debate 24(1):213-237

Spielman SE, Folch D, Nagle N (2014) Patterns and causes of uncertainty in the American Community Survey. Appl Geogr 46:147-157. doi:10.1016/j.apgeog.2013.11.002

Stanke C, Murray V, Amlôt R, Nurse J, Williams R (2012) The effects of flooding on mental health: outcomes and recommendations from a review of the literature. PLoS Curr Disasters. doi:10.1371/ 4f9f1fa9c3cae

Tate E (2012) Social vulnerability indices: a comparative assessment using uncertainty and sensitivity analysis. Nat Hazards 63(2):325-347

Tate E (2013) Uncertainty analysis for a social vulnerability index. Ann Assoc Am Geogr 103(3):526-543. doi:10.1080/00045608.2012.700616

Tate E, Muñoz C, Suchan J (2014) Uncertainty and sensitivity analysis of the HAZUS-MH flood model. Nat Hazards Rev. doi:10.1061/(ASCE)NH.1527-6996.0000167

USACE (2003) Economic guidance memorandum (EGM) 04-01, generic depth-damage relationships for residential structures with basements. U.S. Army Corps of Engineers, Washington, DC

USACE (2010) Cedar River, Cedar Rapids, Iowa, flood risk management project: feasibility study report with integrated environmental assessment. U.S. Army Corps of Engineers, Rock Island

Villarini G, Strong A (2014) Roles of climate and agricultural practices in discharge changes in an agricultural watershed in Iowa. Agric Ecosyst Environ 188:204-211

Villarini G, Smith JA, Baeck ML, Krajewski WF (2011) Examining flood frequency distributions in the midwest U.S. J Am Water Resour As 47(3):447-463. doi:10.1111/j.1752-1688.2011.00540.x

Vincent K (2004) Creating an index of social vulnerability to climate change in Africa. Working Paper 56. Tyndall Centre for Climate Change Research, London

Vu L, VanLandingham MJ (2012) Physical and mental health consequences of Katrina on Vietnamese immigrants in New Orleans: a pre-and post-disaster assessment. J Immigr Minor Health 14(3):386-394

Walker M, Whittle R, Medd W, Burningham K, Moran-Ellis J, Tapsell S (2012) 'It came up to here': learning from children's flood narratives. Child Geogr 10(2):135-150

Ward PJ, Moel Hd, Aerts J (2011) How are flood risk estimates affected by the choice of return-periods? Nat Hazards Earth Syst Sci 11(12):3181-3195 
Werg J, Grothmann T, Schmidt P (2013) Assessing social capacity and vulnerability of private households to natural hazards-integrating psychological and governance factors. Nat Hazards Earth Syst Sci 13(6):1613-1628

Whittle R, Medd W, Deeming H, Kashefi E, Mort M, Twigger-Ross C, Walker G, Watson N (2010) After the rain-learning the lessons from flood recovery in Hull, final project report for "Flood, Vulnerability and Urban Resilience: a real-time study of local recovery following the floods of June 2007 in Hull". Lancaster University, Lancaster

Wisner B, Blaikie P, Cannon T, Davis I (2004) At risk: natural hazards, people's vulnerability and disasters, 2nd edn. Routledge, New York

Yoon DK (2012) Assessment of social vulnerability to natural disasters: a comparative study. Nat Hazards 63(2):823-843. doi:10.1007/s11069-012-0189-2

Zavar E (2015) Residential perspectives: the value of Floodplain-buyout open space. Geogr Rev 105(1):78-95 